\title{
Viselkedési és fiziológiai változók kapcsolata egy vadon élő énekesmadárfajnál*
}

\author{
SZABÓ GYULA ${ }^{1}$, BOROSS NÓRA ${ }^{1,2}$, GARAMSZEGI LÁSZLÓ ZSOLT $^{1,3,4,5}$, \\ JABLONSZKY MÓNIKA ${ }^{1}$, KRENHARDT KATALIN ${ }^{1}$, LACZI MIKLÓ $^{1,6}$, MARKÓ \\ GÁBOR $^{1,7}$, SZÁSZ ESZTER ${ }^{1}$ és TÖRÖK JÁNOS ${ }^{1,8}$

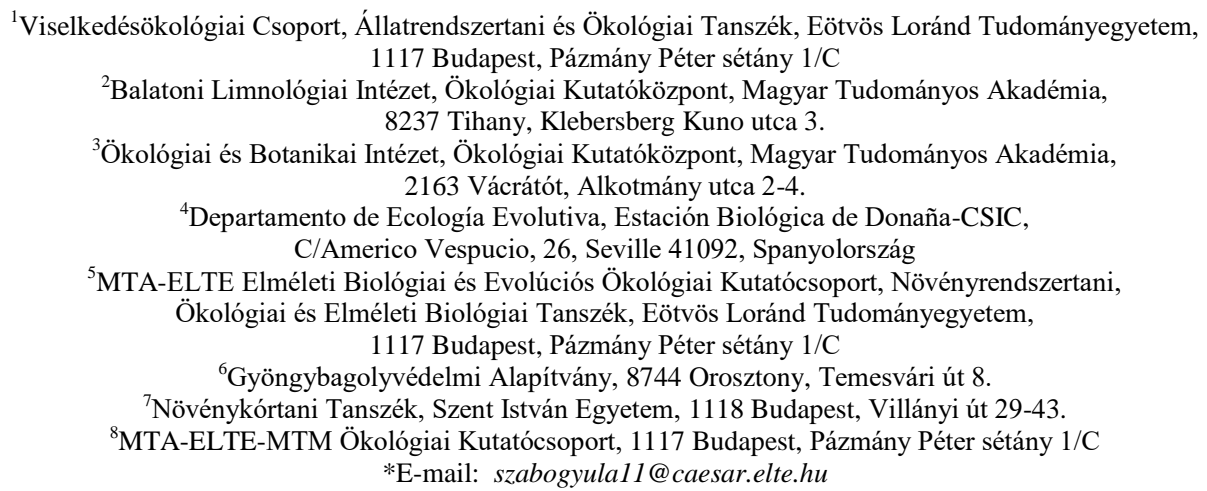

Összefoglalás. A viselkedésökológiai vizsgálatok egyik kiemelt területe az állatok viselkedésének kutatása természetes populációkban. A viselkedési mintázatok leírása mellett egyre több vizsgálat foglalkozik a viselkedések fiziológiai hátterével. Tanulmányunkban az örvös légykapó (Ficedula albicollis) egy vadon élő populációjában vizsgáltuk az oxidatív károsodás mértéke és az egészségi állapot, valamint három viselkedési (idegen tárgy elkerülése, agresszió, kockázatvállalás) változó egymás közötti kapcsolatait. Az oxidatív károsodást a vérplazmában lévő reaktív oxigén metabolitok mennyiségével, az egészségi állapotot a heterofil granulociták és limfociták $(\mathrm{H} / \mathrm{L})$ arányával jellemeztük. A hímektől az udvarláskor és az utódgondozáskor, a tojóktól csak az utódgondozás során vettünk vérmintát. A hímek viselkedését udvarláskor mértük. Eredményeink szerint nem volt különbség az ivarok fiziológiai állapota között. Az oxidatív károsodás mértéke fiatal hímeknél nagyobb volt az utódgondozási időszakban, mint az udvarláskor, míg az idősebb egyedeknél ilyen különbség nem volt kimutatható. A tojók esetében a rosszabb egészségi állapotban lévőket magasabb fokú oxidatív károsodás jellemezte, míg a hímeknél nem volt összefüggés. Az agresszió és a kockázatvállalás mértéke nem mutatott szignifikáns kapcsolatot egyik fiziológiai változóval sem, ugyanakkor az idegen tárgyat kevésbé elkerülő hímek oxidatív stressz szintje magasabb volt, mint az idegen tárgyat jobban elkerülő társaiké. Az oxidatív károsodás növekedését az egyéves egyedeknél a fiókaneveléssel járó terhelés okozhatta, míg az idősebb egyedeknek ebben már volt tapasztalata. Tojóknál nagyobb H/L arány társult a magasabb oxidatív károsodással, a heterofil granulociták pedig szabadgyököket bocsátanak ki, így nagy számuk nagyobb oxidatív károsodáshoz vezethet.

\footnotetext{
* Elhangzott az Állattani Szakosztály 1040. előadóülésén, 2017. május 03-án.
} 
Kulcsszavak: oxidatív stressz, fehérvérsejt arány, agresszió, kockázatvállalás, idegen tárgy elkerülése.

Elfogadva: 2019.11.04.

Elektronikusan megjelent: 2019.12.11.

\section{Bevezetés}

Viselkedésökológiai vizsgálatokban már sokat foglalkoztak az egészségi állapot és az oxidatív stressz rátermettséghatásával. Általában a jobb egészségi állapotban lévő egyedeknek nagyobb a túlélési (LOBATO et al. 2005; KILGAS et al. 2006; KRAMS et al. 2011) és a szaporodási sikere is (HõRAK et al. 1998, MAZEROLLE \& HOBSON 2002, ILMONEN et al. 2003, OCHS \& DAWSON 2008). Az oxidatív stressz és a rátermettség kapcsolatáról is sok az ismeret, azonban nem lehet általános következtetést levonni a köztük lévő kapcsolatról, mert például a környezetnek is nagy hatása van az egyedek oxidatív egyensúlyára (például SPEAKMAN et al. 2015). Mind az egészségi állapotnak, mind az oxidatív stressznek a rátermettséggel való összefüggéséről feltártak már mintázatokat énekesmadaraknál, a fentiekkel ellentétben azonban összességében még továbbra is bizonytalanok az ismereteink a pillanatnyi viselkedés és a hosszabb távon értelmezhető rátermettség közti kapcsolatra vonatkozóan. Örvös légykapónál (Ficedula albicollis TEMMINCK, 1805) kimutatták, hogy a kockázatvállalóbb egyedek adott évi szaporodási sikere nagyobb, túlélési esélye pedig kisebb, mint a kockázatot kerülőké (JABLONSZKY et al. 2018). Ugyanennél a fajnál az agresszió és a rátermettség között van összefüggés: az egyéves egyedek közül az agresszívebbek, míg az idősebbek közül a kevésbé agresszívek tértek vissza nagyobb eséllyel a következő évben költeni (SzÁSZ et al. 2019). A viselkedések hátterében álló fiziológiai folyamatok feltárása segíthet a rátermettség és a viselkedés közti kapcsolat megértésében.

A különböző viselkedésökológiai vizsgálatokban több módszert is javasolnak az egészségi állapot becslésére. Madaraknál a leggyakrabban az immunválasz mértékét (SILD et al. 2011), a parazitáltságot (SzÖLLÖSI et al. 2016), az általános stressz-szintet (GROSS \& SIEGEL 1983), a heterofil granulociták és limfociták (H/L) arányát (GROSS \& SIEGEL 1983, KRAMS et al. 2012) és a hematokritszintet (BOROSS et al. 2012) használják e célból, a vizsgálat kérdésétől függően.

Az egészségi állapotot mutató, általunk vizsgált változó a szakirodalomban is gyakran tanulmányozott $\mathrm{H} / \mathrm{L}$ arány. A limfociták a specifikus immunválaszban vesznek részt, és az alacsony számuk immunszupresszióra utal (COSTANTINI \& DELL'OMO 2006). A heterofil granulociták oxidatív anyagok kibocsátása útján aspecifikusan, a patogén és a szervezet saját sejtjeinek együttes oxidatív károsodásával hatnak (pl. DAVIS et al. 2008). Több faj esetében is az egészségi állapot gyengülésével a $\mathrm{H} / \mathrm{L}$ arány megnőtt. A H/L arány pozitív kapcsolatban volt höstresszel és éhezéssel (MORENO et al. 2002), sugárzás mennyiségével (CAMPLANI et al. 1999), baktériumfertőzéssel (DAVIS et al. 2004), atkaparazitáltsággal (LOBATO et al. 2005) energetikai stresszel (OWEN \& MOORE 2006), valamint a stresszhormon (kortikoszteron) koncentrációjával (GROSS \& SIEGEL 1983). Mindezek alapján, és a módszertani egyszerüségből eredően a H/L arány mérése az egyik legalkalmasabb 
módszer az egészségi állapot becslésére (KRAMS et al. 2012, OTS et al. 1998, NADOLSKI et al. 2006).

Az oxidatív stressz az élölények egy komplex biokémiai állapota, ami akkor lép fel, amikor az egyedben a reaktív oxigén származékok (elsősorban a mitokondriális elektrontranszportláncban felszabaduló szabadgyökök) mennyiségét a szervezet nem tudja kompenzálni kellő mennyiségü antioxidánssal (COSTANTINI 2008). Az oxidatív stresszt az oxidatítv károsodási folyamatok peroxidációs köztitermékeivel, a reaktív oxigén metabolitok (ROM) mennyiségével is szokták jellemezni (COSTANTINI 2008). Jellemzö például, hogy a hosszú távú repülés aktív izommunkája jelentős mennyiségü szabadgyök felszabadulásával jár (COSTANTINI et al. 2008b)

Az oxidatív stressz és a viselkedés összefüggéseit először HEREBORN et al. (2011) írták le fogságban nevelt populációból származó zöldikéken (Carduelis chloris LINNAEUS, 1758). Az idegen tárgyat kerülö viselkedés nem függött össze a ROM mennyiségével (HERBORN et al. 2011). Egy vad kék cinege (Cyanistes caeruleus LINNAEUS, 1758) populációban sem függött össze a ROM és az idegen tárgyat kerülő viselkedés (ARNOLD et al. 2015). Az általunk vizsgált populációban már történt néhány vizsgálat a viselkedés és a fiziológiai állapot kapcsolatának felderítésére. E vizsgálatok eredményei azt mutatták, hogy az immunrendszer aktivitása nem áll kapcsolatban az egyedek kockázatvállalásával (GARAMSZEGI et al. 2015), ahogy az ürülékben mérhető kortikoszteron koncentrációjával sem (GARAMSZEGI et al. 2012).

A ROM és a H/L arány kapcsolatát az agresszióval valamint a kockázatvállalással eddig természetes madárpopulációban ismereteink szerint még nem vizsgálták, valamint a H/L arány és az idegen tárgyat kerülő viselkedés kapcsolatát sem.

Az örvös légykapó egy odúköltő, hosszú távú vonuló énekesmadárfaj, melynek egy természetes populációjában vizsgáltuk a vonulással járó fokozott fizikai megterhelés egészségi állapotra és oxidatív károsodásra gyakorolt hatását. Ezen kívül a fiziológiai változók egymás közötti kapcsolatát, valamint a fiziológia és a viselkedés változók közötti kapcsolatot is elemeztük. Az alábbi fö kérdéseinkre kerestük a választ:

1) Függ-e a H/L arány és a ROM az egyedek ivarától? Azt vártuk, hogy az ivartól nem függ az egyedek fiziológiai állapota. Mindkét ivar neveli a fiókákat, így hasonló megpróbáltatásokkal kell megküzdeniük.

2) Eltér-e a hímek esetében a szaporodási szezon két időszaka (udvarlás, fiókanevelés) között a H/L arány, illetve a ROM szintje? Várhatóan az egyedek fiziológiai állapota romlik a fiókanevelés okozta megterhelés hatására. A fiókák etetésébe fektetik az energiát, nem pedig saját fiziológiai állapotuk fenntartására.

3) Milyen kapcsolatban van a vadon élö örvös légykapók H/L aránya és ROM értéke egymással? Azt vártuk, hogy a jobb egészségi állapotban lévő egyedeknek kisebb az oxidatív károsodása. Az egyedek fiziológiai állapotát a két változó hasonlóan tükrözi.

4) Összefüggnek-e egymással a viselkedési változók (idegen tárgy elkerülése, agresszió, kockázatvállalás) és a $\mathrm{H} / \mathrm{L}$ arány, illetve a ROM szint? A viselkedési változók és a $\mathrm{H} / \mathrm{L}$ arány, valamint a ROM szintje között nem vártunk kapcsolatot. 


\section{Anyag és módszer}

$\mathrm{Az}$ adat- és mintagyüjtés a Pilis-Visegrádi-hegységben $\left(47^{\circ} 43^{\prime} \mathrm{E} \mathrm{E}, 1^{\circ} 01^{\prime} \mathrm{K}\right), 2014$ 2015-ben történt, gyertyános-tölgyes erdőkben kialakított mesterséges odútelepeken. A szaporodási időszakban odúcsapdával fogtuk meg az egyedeket a mintavételhez. A mintavételezés a szaporodási időszak két szakaszában történt: az udvarlási időszakban (április közepétől május elejéig) és a fiókanevelési időszakban (május utolsó harmadától nyár közepéig). Az udvarlási időszakban a hímek odút foglalnak, ekkor a tojókat még nem lehet megfogni, így ebben az időszakban csak a hímeket vizsgáltuk. Fiókanevelés alatt mindkét ivartól vettünk mintát. A hímek korát (egyéves vagy idősebb) a tollazatuk alapján határoztuk meg (DEMONGIN 2016). Tojók esetében csak a rekrutáknál, (melyek fiókakorban meg lettek gyürüzve) határozható meg a pontos kor, azonban a legtöbb egyed nem rekruta, ezáltal az elemzéseinkbe nem tudtuk bevinni ezt a változót.

\section{Fiziológiai változók}

Az udvarlási időszakban 2014-ben 8, 2015-ben 10 hímtől vettünk vérmintát, a viselkedésük megfigyelését követően (lásd alább). A fiókanevelési időszakban 2014-ben 24 hímtől és 28 tojótól, 2015-ben 44 hímtől és 59 tojótól vettünk vérmintát. Vérvételkor a brachiális vénán injekciós tüvel sebet ejtettünk, és a kis mennyiségü vért (kb. $40 \mu \mathrm{l}, 1$ csepp) heparinizált kapillárisokba gyüjtöttük, aminek egyik részéből vérkenetet készítettünk a H/L arány meghatározáshoz, egy másik részét pedig a ROM mérésére használtuk. A kapillárisokban lévő vérmintákat a mintavételtől számított 5 órán belül centrifugáltuk 10 percig, 10 $000 \mathrm{rpm}$-en a plazma és a sejtes rész elválasztásához. A plazmát $-20{ }^{\circ} \mathrm{C}$-on tároltuk a $\mathrm{ROM}$ meghatározásáig. Az egészségi állapot becslésére a $\mathrm{H} / \mathrm{L}$ arányt használtuk. A keneteket 10\%-os Giemsa-festékkel (G4507; Sigma-Aldrich, Budapest, Magyarország) festettük 50 percig, majd desztillált vízzel kimostuk a maradék festéket a mintából. A keneteken lévő heterofil granulocitákat és limfocitákat, Zeiss Axioskop 2 fénymikroszkópban (Carl Zeiss Inc., Oberkochen, Germany), immerziós olajjal 1000-szeres nagyítás mellett számoltuk. A látómező közepét egy ColorView II kamera által számítógépen jelenítettük meg az Olympus Soft Imaging analySIS work 5.0 program (Soft Imaging, Munster, Germany) segítségével. 100 látómezőt vizsgáltunk meg. Ezeken legalább az egyik sejttípusból minimum 10 db-nak kellett előkerülnie. Amennyiben ez nem teljesült, akkor további 50 látómezőt néztünk meg, ekkor elég volt, ha legalább az egyik sejttípusból 8 db elökerült. Ha ez a kritérium sem teljesült, akkor összesen 200 látómezőt vizsgáltunk meg. Két esetben előfordult, hogy az egyik sejttípusból nem találtunk egy darabot sem, akkor ennek értékét 0,1-nek vettük, hogy lehessen arányt számolni. Nem voltak ezeknél szélsőségesebb arányok azon minták között, ahol mindkét sejttípus előfordult. Kenetenként átlagosan 12,26 db fehérvérsejt került elö (minimum 3 db és maximum 45 darab). Hogy a módszer megbízhatóságát ellenőrizzük, véletlenszerüen kiválasztott keneteken megismételtük a számolást. Pearsonkorrelációval vizsgáltuk a $\mathrm{H} / \mathrm{L}$ arány repetabilitását, amely szignifikánsnak bizonyult $(\mathrm{r}=0,861 ; \mathrm{p}=0,001 ; \mathrm{n}=11)$. Ismételt mérések esetén a $\mathrm{H} / \mathrm{L}$ arányok átlagát használtuk az elemzésben. Az oxidatív károsodás mértékének meghatározására a ROM vérplazmában mért értékét használtuk, a mérést a d-ROM (Diacron International, Grossetto, Olaszország) teszttel végeztük (részletesen lásd: MARKÓ et al. 2011). A ROM a szabadgyökök által per- 
oxidált makromolekulák (lipidek, fehérjék, nukleinsavak) mennyiségét mutatja ( $\mathrm{mmol}^{*} \mathrm{I}^{-1}$ $\mathrm{H}_{2} \mathrm{O}_{2}$ ekvivalensben).

\section{Viselkedési változók}

A tavaszi vonulásból a hímek korábban érkeznek meg. Ekkor minden nap ellenőriztük, hogy érkezett-e olyan új hím a területre, amely egy odú mellett az udvarlási viselkedést mutatta (például éneklés, odú bemutatása), és feltételeztük, hogy ez az odú az egyed kiválasztott fészkelőhelye. Amikor észleltünk ilyen hímet, a párba állás előtt három viselkedési változót mértünk: az idegen tárgy elkerülését, az agresszivitást és a kockázatvállalást. A méréseket egymás után, a fentebbi sorrendben, néhány perc különbséggel végeztük. Mivel a tojók ekkor még sok esetben nem választottak párt, a viselkedési változóikat nem mértük. A viselkedési változók mérései során GARAMSZEGI et al. (2006, 2009) módszereit követtük.

Az idegen tárgyat elkerülő viselkedés (felfedezési készség) mérése során először kontrollként egy a vizsgálat helyszínétől távolabb fogott - így a fokális egyedek számára ismeretlen - csali tojót raktunk az odú tetejére egy kalitkában $(15 \times 20 \times 15 \mathrm{~cm})$. Ebben a tesztben azt mértük, hogy mennyi idő telik el a hím érkezése és az odút bemutató viselkedésének kezdete között (azaz addig a pillanatig, amíg a hím először az odú nyílására száll). Ezután a tesztet úgy egészítettük ki, hogy egy A/6-os méretü, színes, absztrakt formájú ábrát megjelenítő lapot rögzítettünk az odú bejárata alá, és mértük az odú mutatásáig eltelt időt (latenciát). Amennyiben 300 másodpercen belül nem szállt le a hím, 301 másodpercnek vettük az értéket. A teszt befejeztével a csali tojót levettük az odúról. A lapos teszt latencia értékéből kivontuk a lap nélküli, kontrolként mutatott latencia értékét, így minél nagyobb a különbség értéke, annál jobban kerüli el az idegen tárgyat a hím. (GARAMSZEGI et al. 2009).

Ezután a madarak agresszivitását mértük. A hímeket egy szimulált territoriális támadásnak tettük ki. Ketrecben $(15 \times 20 \times 15 \mathrm{~cm})$ egy élö, a vizsgálat helyszínétől távolabb fogott csali hímet helyeztünk el az odú 1-2 méteres körzetében. Miután felfedtük a ketrecet, 30 méterre eltávolodtunk az odútól, és mértük, hogy mennyi idő után támadja meg a fokális hím a csalit. Az idő mérését akkor kezdtük, amikor a hím megjelent a területen, és észrevette a betolakodót, valamint akkor fejeztük be, amikor a hím elöször hozzáért a ketrechez legalább 1 másodpercig, és közben harci szándékát mutatta (tollborzolás, csipkedés). Amenynyiben a hím nem támadott 300 másodpercen belül, a mért időt 301 másodpercnek vettük (SzÁsz et al. 2019). Ez az időtartam fordítottan arányos a madár agresszivitásával.

A harmadik viselkedési változó a menekülést kiváltó távolság volt, amely az a minimális távolság, amennyire a madár közel engedi magához a ragadozót, mielőtt elmenekülne. Ezzel az egyedi kockázatvállalást jellemeztük. A mérés során a ragadozót maga a mérést végző személy képviselte. Az agresszió mérése során akkor, amikor a hím elkezdte a támadását, egy standardizált háttéraktivitást (agresszív területvédő viselkedést) értünk el a madárnál. Ekkor a tesztelést végző személy elkezdett közelíteni a madár felé kb. 25-30 méter távolságból. Amikor elrepült a hím, mindig megállt a tesztelö, és megvárta a hím visszatértét a kalitkához, majd folytatta a megközelítést, ha a hím egy percen belül visszatért. Ha egy percen belül nem tért vissza a hím, lemértük a csali és a tesztelő közti távolságot. Minél kisebb ez a távolság, annál kockázatvállalóbb az egyed. Ismétlés esetén a mért értékeket átlagoltuk. Ismételt mérés 11 esetben történt, a mérések repetábilisak voltak. A méréseket 
több személy is végezte, azonban az általunk mért viselkedési változók repetabilitását nem befolyásolja a mérést végző személye (GARAMSZEGI et al. 2009; MARKÓ et al. 2016).

A terepi körülmények között számos zavaró tényező (látótávon kívülre repül a madár, megzavarja egy másik faj egyede a mérést, stb.) miatt előfordult, hogy nem tudtuk minden madár összes viselkedési változóját mérni.

\section{Statisztikai elemzések}

QQ plottal, illetve Kolmogorov-Smirnov-tesztel ellenőriztük a változók eloszlását, melyek a H/L kivételével nem tértek el a normális eloszlástól. A H/L arányt $-\frac{1}{\sqrt{x+0,5}}$ transzformációval tettük normális eloszlásúvá. Kétmintás, független Student-féle t-próbával vizsgáltuk a fiókaneveléskor mért ROM és H/L ivarok közötti eltérését, valamint a hímeknél az udvarlási és a fiókanevelési szakasz közötti eltérését. A ROM összehasonlítását a két időszak között külön az egyéves (udvarláskor: $n=7$, fiókaneveléskor: $n=11$ ) és külön az idösebb hímeknél (udvarláskor $n=8$, fiókaneveléskor $n=22$ ) is el tudtuk végezni, míg a H/L arány esetében a két korcsoport mintaelemszáma jelentősen eltért (egyéves: $n=5$; idősebb: $\mathrm{n}=40$ ), így együtt vizsgáltuk őket. Általános lineáris modellekkel vizsgáltuk a ROM és a $\mathrm{H} / \mathrm{L}$ arány összefüggését a fiókanevelési időszakban: a függő változó volt a ROM, az ivar a magyarázó kategóriaváltozó, a H/L pedig a magyarázó folytonos változó. Vizsgáltuk a magyarázó változók interakcióját is. A modelleknél a lépésenként visszafelé irányuló modellegyszerüsítés módszerét alkalmaztuk. A viselkedési és a fiziológiai változók kapcsolatát csak hímek esetében, az udvarlási időszakban vizsgáltuk, Pearson-korrelációkkal. A statisztikai vizsgálatokat a Statistica v8.0 programmal végeztük.

\section{Eredmények}

A tojók és a hímek fiókanevelési időszakban mért fiziológiai változói között nem volt különbség $(\mathrm{H} / \mathrm{L}: \mathrm{t}=0,02, \mathrm{p}=0,98, \mathrm{n}=94$; ROM: $\mathrm{t}=0,68, \mathrm{p}=0,50, \mathrm{n}=73)$. A hímek H/L arányának vizsgálatakor az udvarlási és a fiókanevelési időszak között sem volt szignifikáns különbség $(\mathrm{t}=1,16, \mathrm{p}=0,25, \mathrm{n}=43)$. A ROM-szint az idősebb hímeknél nem különbözött az udvarlási és a fiókanevelési időszak között $(\mathrm{t}=-0,24 ; \mathrm{p}=0,81 ; \mathrm{n}=30)$, az egyéveseknél az udvarlási időszakban mért ROM-szint tendenciózusan alacsonyabb volt $(\mathrm{t}=-1,76 ; \mathrm{p}=0,097 ; \mathrm{n}=18 ; 1$. ábra). A hímeknél a $\mathrm{H} / \mathrm{L}$ arány és a $\mathrm{ROM}$-szint nem függött össze $(\mathrm{F}=0,34 ; \mathrm{df}=1,12 ; \mathrm{p}=0,57)$, ellenben a tojókkal, ahol a rosszabb egészségü egyed magasabb ROM-szinttel rendelkezett $(\mathrm{F}=5,95 ; \mathrm{df}=1,9 ; \mathrm{p}=0,037 ; 2$. ábra).

Az udvarlási időszakban a ROM-szint negatívan függött össze hímek esetében az idegen tárgyat elkerülő viselkedéssel $(\mathrm{r}=-0,94 ; \mathrm{p}=0,027 ; \mathrm{n}=7 ; 3$. ábra), azaz az idegen tárgyat jobban elkerülő hímeknek alacsonyabb a ROM-szintje. A többi viselkedési változó a hímeknél nem függött össze a két fiziológiai változóval (összes p >0,2). 


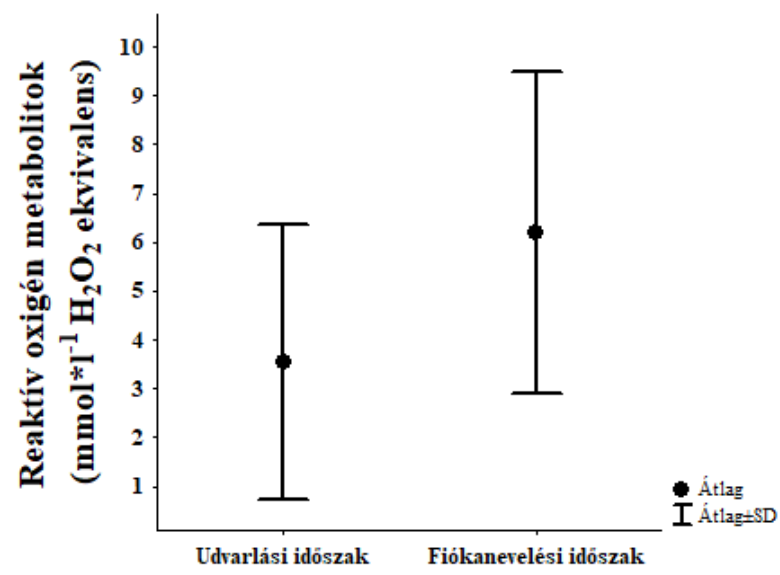

1. ábra. Az egyéves örvös légykapó hímek reaktív oxigén metabolit (ROM) szintje ( $n=18)$.

Figure 1. ROM levels of one year old male collared flycatchers during the courtship and chick-rearing period. The dots show the mean values, the whiskers show the standard deviation $(n=18)$.

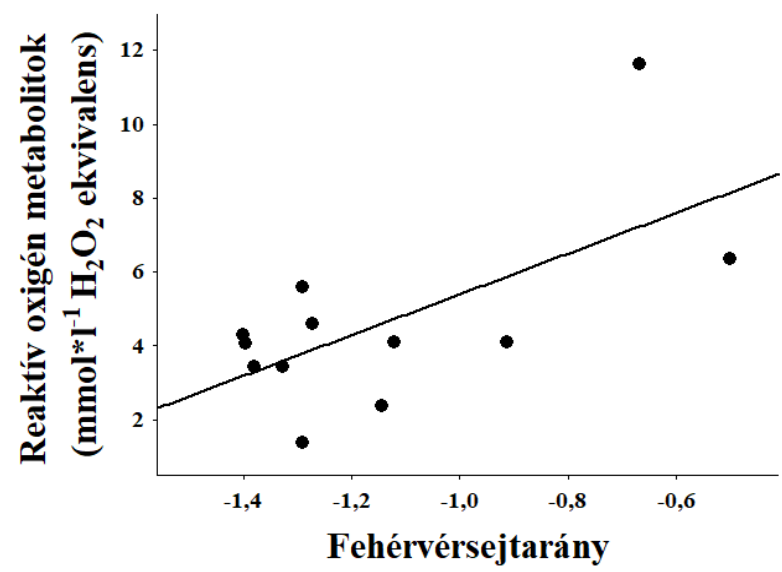

2. ábra. Transzformált fehérvérsejtarány (heterofil granulocita/limfocita) és a ROM-szint (oxidatív károsodás) összefüggése örvös légykapó tojóknál a fiókanevelési időszakban.

A transzformáció a $-1 /$ gyök $(x+0,5)$ képlet alapján történt.

Figure 2. Relationship between transformed leukocyte ratio (heterophil granulocyte/limphocyte) and ROM levels in female flycatchers during the brood-rearing period.

Leukocyte ratio is transformed by $-1 /$ square $\operatorname{root}(\mathrm{x}+0.5)$. 


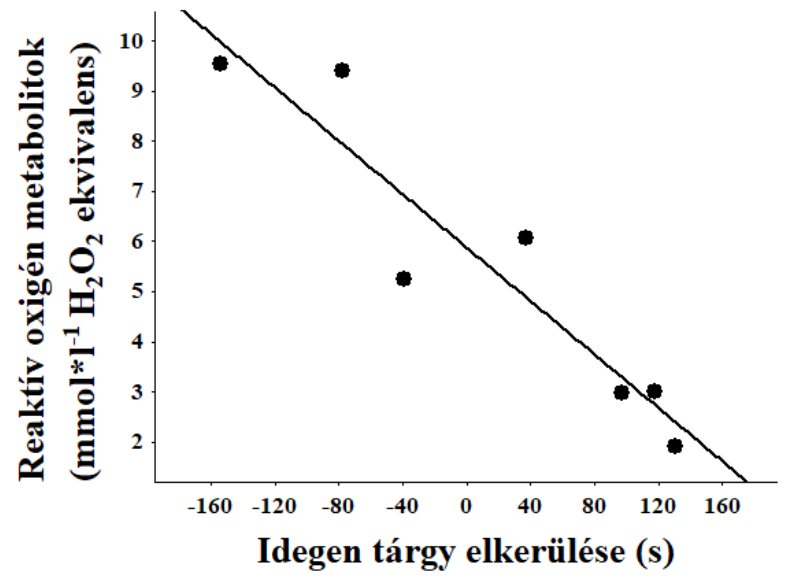

3. ábra. Örvös légykapó hímek explorációja a ROM-szint (oxidatív károsodás) függvényében.

Figure 3. Relationship between exploration and oxidative damage (ROM level) of male collared flycatchers during the courtship period.

\section{Értékelés}

Az egyedek fiziológiai állapota nem függött az ivartól, ami egyezik a predikciónkkal. Az udvarlási és a fiókanevelési időszak között csak az egyéves hímek esetében romlott az egyedek fiziológiai állapota: a ROM mennyisége megnőtt, ami részben alátámasztja a predikciónkat. A jobb egészségi állapotban lévő tojókban alacsonyabb volt az oxidatív károsodás mértéke. Ezzel szemben a hímeknél nem tapasztaltunk összefüggést, így ezt a predikciónkat is csak részben támasztották alá az eredmények. A H/L arány nem volt összefüggésben egyik viselkedési változóval sem, amit vártunk is, azonban a ROM a kockázatvállalással összefüggésben volt, ami ellent mond predikciónknak.

Ivarok közti különbséget kimutattak egy másik, szintén odúlakó énekesmadárfajnál, a széncinegénél (Parus major LiNNAEUS, 1758). A tojók H/L szintje magasabbnak bizonyult a hímekénél, melyet az okozott, hogy több heterofil granulocitájuk volt, ugyanakkor a limfociták száma nem tért el a hímekétől (OTS et al. 1998). Ennek hátterében az ivarok egészségi állapota közötti különbség is állhat, azonban az sem kizárható, hogy csak a két ivar hormonrendszere közti különbség okozza az eltérést (OTS et al. 1998). Azonban, hasonlóan egy házi pirókon (Haemorhous mexicanus PALLAS, 1770) végzett vizsgálat eredményeihez (DAVIS et al. 2004), mi sem találtunk különbséget a két ivar H/L aránya között.

A H/L arány és a ROM szezonon belüli variabilitásának vizsgálatával kimutattuk, hogy az egyéves hímek $\mathrm{H} / \mathrm{L}$ aránya nem, de a ROM-szintje nagyobb volt a fiókaneveléskor mintázott egyedekben, mint az udvarláskor mintázottakban. Ez a különbség csak marginálisan volt szignifikáns. Az egészségi állapotra utaló egy másik vérparaméter, a hematokrit szintje ugyanakkor fordított mintázatot mutatott (BoROSS et al. 2012). Feltételezésünk szerint az egyéves hímekben az indokolhatja a ROM-szint eltérését a két időszak között, hogy először 
nevelnek utódot, és még nincs tapasztalatuk az utódgondozásban. Ezért a fiókanevelés nagyobb megterhelést jelent számukra, mint a tapasztaltabb, idősebb hímeknek. Hasonló korcsoportbeli mintázatot találtak vörösbegyek (Erithacus rubecula LINNAEUS, 1758) öszi vándorlása során. Az egy évnél idősebb egyedek pihenés alatti táplálkozással antioxidánsokban gazdagabb táplálékot fogyasztottak, valamint magasabb volt az enzimatikus antioxidánsok mennyisége a vérükben, mint az először vonulóknak. Így a tapasztaltabb egyedek megnövelhették a vérplazma gyökfogó képességüket, így tapasztalatuk segítségével lecsökkenthették a szabadgyökök mennyiségét, ami a hosszú távú repüléssel járó izommunkából ered (JENNI-EIERMANN et al. 2014). A ROM növekedéséhez az is hozzájárulhat még, hogy mind a specifikus, mind az aspecifikus immunválasz során szabadgyökök szabadulnak fel nagy mennyiségben (MAXWELl \& RoBERTSON 1998, CosTANTINI \& DELL'OMO 2006). Ezzel összhangban, SzÖLLÖSI et al. (2016) azt tapasztalták, hogy a parazitáltság prevalenciája lecsökken a fiókanevelés idejére.

A fiziológiai változók kapcsolatának vizsgálatakor a $\mathrm{H} / \mathrm{L}$ arány és a ROM csak a tojókban függött össze egymással, aminek hátterében az is állhat, hogy a H/L arány kialakításának hátterében különböző korlátozó tényezők lehetnek a két ivarnál (OTS et al. 1998). Minél rosszabb volt az egyedek egészségi állapota, annál magasabb volt az oxidatív károsodás szintje a vérplazmában. A heterofil granulociták olyan módon is részt vesznek az immunválaszban, hogy erősen oxidatív anyagokat bocsátanak ki a kórokozókra (MAXWELL \& ROBERTSON 1998). Ez a védekezés a saját szöveteket is károsíthatja, így ennek hatására növekedhetett meg az egyed ROM-szintje.

A légykapók kockázatvállalása és agresszív viselkedése nem függött össze sem a H/L aránnyal, sem pedig az oxidatív károsodással. A H/L arány nem függött össze az idegen tárgyakat kerülő viselkedéssel sem. Az általunk vizsgált populációban korábbi vizsgálatokban ugyanezek a viselkedési változók nem függtek össze az egészségi állapotot jellemző két másik tényezővel, a kortikoszteronszinttel és az immunrendszer aktiválásával sem (GARAMSZEGI et al. 2012, GARAMSZEGI et al. 2015). A H/L arány tükrözi az egyed stresszszintjét, így eredményünk összhangban van azzal, hogy a kortikoszteronnal sem állt a kapcsolatban az egyedek viselkedése.

Az aktív izommunka rövid távon gyorsan megnöveli az oxidatív károsodás mértékét (COSTANTINI et al. 2008b), aminek hatása a ROM-szintben már néhány óra alatt megjelenik. Az idegen tárgyakat kevésbé elkerülő hímek az odút közelítő idegen ingereket több esetben, távolabbról odarepülve vizsgálhatják meg, így többet repülhetnek, ezáltal magasabb lehet az anyagcsereszintjük. Az alapanyagcsere és az explorációs viselkedés negatív kapcsolatban áll széncinege tojóknál: a nagyobb felfedezési készséggel rendelkező egyedeknek alacsonyabb az alapanyagcsere-szintjük. Hímeknél ez az összefüggés enyhén pozitív, azonban nem szignifikáns (BOUWHUIS et al. 2014). A magasabb alapanyagcsere-szinttel magasabb ROM-szint társul (COSTANTINI 2008), így elképzelhetö, hogy az örvös légykapónál az idegen tárgyat kerülő viselkedés és a ROM közti összefüggés hátterében az alapanyagcsere-szintek közötti különbség áll. Eredményünk szerint az idegen tárgyakat kevésbé elkerülő légykapók ROM-szintje is magasabb, azonban ez az összefüggés fogságban tartott zöldikéknél (HERBORN et al. 2011) és vadon élő kék cinegéknél (ARNOLD et al. 2015) sem volt kimutatható. A mi vizsgálatunk egy természetes populációban történt, a mérések a madarak természetes környezetében zajlottak, míg ARNOLD et al. (2015) néhány napon keresztül fogságban tartott egyedeket vizsgált, HERBORN et al. (2011) pedig egy fogságban élö 
populációt vizsgált. Fajon belül is lehet különbség vad, illetve fogságban tartott populációk oxidatív állapotában: vad zöldikék oxidatív károsodása körülbelül a kétszerese volt a fogságban felneveltekének (HõRAK et al. 2006, HERBORN et al. 2011). Ezáltal jelentős különbség lehet a ROM és a többi változó kapcsolatában populációk között is, hiszen a laboratóriumban rendelkezésre álló korlátlan mennyiségü táplálék segítheti a hatékonyabb antioxidáns rendszer kialakulását. Nemcsak a mennyiség, de a táplálék minősége is, például karotinoidtartalma növelheti a szervezet szabadgyökfogó képességét (COHEN et al. 2007). Az idegen tárgyat elkerülő viselkedésnek hosszú távon hatása lehet a rátermettségre, hiszen az egyed nagyobb területet járhat be, új dolgokat fedez fel, így több táplálékot találhat, rábukkanhat új búvó- és éjszakázóhelyekre, költésre alkalmas odúkra, továbbá az udvarlás alatt több tojóval találkozhat.

Házi egereken (Mus musculus LINNAEUS, 1758) végzett kísérlet alapján a nagyfokú agresszióra szelektált genetikai vonal egyedeiben magasabb volt a plazma szabadgyökfogó képessége, viszont ROM-ban és oxidatív egyensúlyban nem különböztek a mérsékelt agresszióra szelektáltakétól. A ROM negatív kapcsolatban állt az agresszióval az agresszívabb vonalban (COSTANTINI et al. 2008a). Elképzelhető, hogy az örvös légykapó esetében az oxidatív stressz egy másik aspektusában mutatkozik mintázat az agresszióval, amit a ROM mértéke nem tükröz megfelelően. Eddig kevés vizsgálat irányult az általunk vizsgált viselkedések genetikai hátterének feltárására, pedig ezek az ismeretek sokat segíthetnek a viselkedések hátterében álló élettani folyamatok megértésében.

Vizsgálatunk rámutat arra, hogy eltérő fajoknál más-más mintázatot kaphatunk az egyed viselkedése és az egészségi, valamint az oxidatív állapota között. Ez az eltérés eredhet a fajok fiziológiai és viselkedésbeli különbségéből, valamint módszertani különbségekből is. Ezeket a mintázatokat tovább befolyásolhatja, hogy a vizsgált egyedek vadon vagy laboratóriumi körülmények között élnek.

Köszönetnyilvánítás. Szeretnénk megköszönni a segítséget a Viselkedésökológiai Csoport tagjainak, valamint a Pilisi Parkerdő Zrt-nek a terepmunka lehetővé tételét. A kutatások anyagi hátterét az NKFIH K115970 számú pályázat biztosította. A madarak megfogását és a szövetminták vételét a Közép-Duna-völgyi Környezetvédelmi, Természetvédelmi és Vízügyi Felügyelőség (KTVF 109498/2013) és a Pest Megyei Kormányhivatal Környezetvédelmi és Természetvédelmi Főosztálya (PE/KTF/11978-6/2015) engedélyezte. Az Emberi Erőforrások Minisztériuma ÚNKP-18-2 kódszámú Új Nemzeti Kiválóság Programja (ÚNKP-18-2-I-ELTE-545) által SZABÓ GYULÁnak nyújtott támogatása segítette a kutatások megvalósulását. MARKÓ GÁBORt az Emberi Erőforrások Minisztériuma által meghirdetett Felsőoktatási Intézményi Kiválósági Program (20430-3/2018/FEKUTSTRAT) támogatta.

\section{Irodalomjegyzék}

Arnold, K. E., Herborn, K. A., AdAm, A. \& AleXAnder, L. (2015): Individual variation in the oxidative costs of personality traits. Functional Ecology 29: 522-530. https://doi.org/10.1111/13652435.12375 
Boross, N., Markó, G., Laczi, M., Garamszegi, L. Z., Hegyi, G., Herényi, M., Kiss, D., Nagy, G., Rosivall, B., SzÖLlÖSI E. \& TÖRÖK, J. (2012): Sources of variation in haematocrit in the Collared Flycatcher (Ficedula albicollis). Ornis Hungarica 20: 64-72. https://doi.org/10.2478/orhu-2013-0008

Bouwhuis, S., Quinn, J. L., Sheldon, B. C. \& Verhlust, S. (2014): Personality and basal metabolis rate in a wild bird population. Oikos 123: 56-62. https://doi.org/10.1111/j.1600-0706.2013.00654.x

Camplani, A., Saino, N. \& Moller, A. P. (1999): Carotenoids, sexual signals and immune function in barn swallows from Chernobyl. Proceedings of the Royal Society B-Biological Sciences 266: 1111-1116. https://doi.org/10.1098/rspb.1999.0751

Cohen, A., Klasing, K. \& Ricklefs, R. (2007): Measuring circulating antioxidants in wild birds. Comparative Biochemistry and Physiology - B Biochemistry and Molecular Biology 147: 110 121. https://doi.org/10.1016/j.cbpb.2006.12.015

Costantini, D. \& Dell'Omo, G. (2006): Effects of T-cell-mediated immune response on avian oxidative stress. Comparative Biochemistry and Physiology Part A: Molecular \& Integrative Physiology 145: 137-142. https://doi.org/10.1016/j.cbpa.2006.06.002

Costantini, D. (2008): Oxidative stress in ecology and evolution: Lessons from avian studies. Ecology Letters 11: 1238-1251. https://doi.org/10.1111/j.1461-0248.2008.01246.x

Costantini, D., Carere, C., Caramaschi, D. \& Koolhaas, J. M. (2008a): Aggressive and nonaggressive personalities differ in oxidative status in selected lines of mice (Mus musculus). Biology Letters 4: 119-122. https://doi.org/10.1098/rsbl.2007.0513

Costantini, D., Dell'Ariccia, G. \& LiPP, H. P. (2008b): Long flights and age affect oxidative status of homing pigeons (Columba livia). The Journal of Experimental Biology 211: 377-381. https://doi.org/10.1242/jeb.012856

Davis, A. K., CooK, K. C. \& Altizer, S. (2004): Leukocyte Profiles in Wild House Finches with and without Mycoplasmal Conjunctivitis, a Recently Emerged Bacterial Disease. EcoHealth 1: 362373. https://doi.org/10.1007/s10393-004-0134-2

DAvis, A. K., MAnEy, D. L. \& MAERZ, J. C. (2008): The use of leukocyte profiles to measure stress in vertebrates: A review for ecologists. Functional Ecology 22: 760-772. https://doi.org/10.1111/j.1365-2435.2008.01467.x

Demongin, L. (2016): Identification guide to birds in the hand. Laurent Demongin, BeauregardVendon, $392 \mathrm{pp}$.

Garamszegi, L. Z., Rosivall, B., Hegyi, G., SzÖllösi, E., TöröK, J. \& Eens, M. (2006): Determinants of male territorial behavior in a Hungarian collared flycatcher population: plumage traits of residents and challengers. Behavioral Ecology and Sociobiology 60: 663-671. https://doi.org/10.1007/s00265-006-0210-4

GARAmsZeGi, L. Z., EENS, M. \& TÖRÖK, J. (2009): Behavioural syndromes and trappability in freeliving collared flycatchers, Ficedula albicollis. Animal Behaviour 77: 803-812. https://doi.org/10.1016/j.anbehav.2008.12.012

Garamszegi, L. Z, Rosivall, B., Rettenbacher, S., Markó, G., ZsebÖK, S., SzÖllösi, E., Eens, M., POTTI, J. \& TÖRÖK, J. (2012): Corticosterone, avoidance of novelty, risk-taking and aggression in a wild bird: no evidence for pleiotropic effects. Ethology 118: 621-635. https://doi.org/10.1111/j.1439-0310.2012.02049.x

Garamszegi, L. Z., Zagalska-Neubauer, M., Canal, D., Markó, G., SzÁsz, E., ZseböK, S., SzÖllösI, E., HERCZEG, G. \& TÖRÖK, J. (2015): Malaria parasites, immune challenge, MHC variability, and predator avoidance in a passerine bird. Behavioral Ecology 26: 1291-1302. https://doi.org/10.1093/beheco/arv077 
Gross, W. B. \& SIEGEL, H. S. (1983): Evaluation of the heterophil/lymphocyte ratio as a measure of stress in chickens. Avian Diseases 27: 972-979. https://doi.org/10.2307/1590198

Herborn, K. A., Coffey, J., Larcombe, S. D., Alexander, L. \& Arnold, K. E. (2011): Oxidative profile varies with personality in European greenfinches. The Journal of Experimental Biology 214: 1732-1739. https://doi.org/10.1242/jeb.051383

HõRAK, P., OTS, I. \& MuRUMÄGI, A. (1998). Haematological health state indices of reproducing Great Tits: A response to brood size manipulation. Functional Ecology 12: 750-756. https://doi.org/10.1046/j.1365-2435.1998.00244.x

HõRaK, P., Zilmer, M., SaKs, L., Ots, I., KarU, U. \& Zilmer, K. (2006): Antioxidant protection, carotenoids and the costs of immune challenge in greenfinches. The Journal of Experimental Biology 209: 4329-4338. https://doi.org/10.1242/jeb.02502

Ilmonen, P., Hasselquist, D., LANGefors, Å. \& Wiehn, J. (2003): Stress, immunocompetence and leukocyte profiles of pied flycatchers in relation to brood size manipulation. Oecologia 136: 148 154. https://doi.org/10.1007/s00442-003-1243-2

Jablonszky, M., Szász, E., Krenhardt, K., Markó, G., Hegyi, G., Herényi, M., Laczi, M., Nagy, G., Rosivall, B., SzÖllösi, E., TÖRÖK, J. \& Garamszegi, L. Z. (2018): Unravelling the realtionship between life history, behaviour and condition under the pace-of-life syndromes hypothesis using long-term data from a wild bird. Behavioral Ecology and Sociobiology 72: 52. https://doi.org/10.1007/s00265-018-2461-2

Jenni-Eiermann, S., Jenni, L., Smith, S. \& Costantini, D. (2014): Oxidative stress in endurance flight: An unconsidered factor in bird migration. PLOS ONE 9: 1-6. https://doi.org/10.1371/journal.pone.0097650

Kilgas, P., Mänd, R., MäGI, M. \& TILgaR, V. (2006): Hematological parameters in brood-rearing great tits in relation to habitat, multiple breeding and sex. Comparative Biochemistry and Physiology - A Molecular and Integrative Physiology 144: 224-231. https://doi.org/10.1016/j.cbpa.2006.02.038

Krams, I., Cirule, D., Krama, T. \& Vrublevska, J. (2011): Extremely low ambient temperature affects haematological parameters and body condition in wintering Great Tits (Parus major). Journal of Ornithology 152: 889-895. https://doi.org/10.1007/s10336-011-0672-7

Krams, I., Vrublevska, J., Cirule, D., Kivleniece, I., Krama, T., Rantala, M. J., Sild, E. \& HõRAK, P. (2012): Heterophil/lymphocyte ratios predict the magnitude of humoral immune response to a novel antigen in great tits (Parus major). Comparative Biochemistry and Physiology - A Molecular and Integrative Physiology 161: 422-428. https://doi.org/10.1016/j.cbpa.2011.12.018

Lobato, E., Moreno, J., Merino, S., SAnZ, J. J. \& Arriero, E. (2005): Haematological variables are good predictors of recruitment in nestling pied flycatchers (Ficedula hypoleuca). Ecoscience 12: 27-34. https://doi.org/10.2980/i1195-6860-12-1-27.1

Markó, G., Costantini, D., Michl, G. \& TöröK, J. (2011): Oxidative damage and plasma antioxidant capacity in relation to body size, age, male sexual traits and female reproductive performance in the collared flycatcher (Ficedula albicollis). Journal of Comparative Physiology B: Biochemical, Systemic, and Environmental Physiology 181: 73-81. https://doi.org/10.1007/s00360-010-0502-x

Maxwell, M. H. \& Robertson, G. W. (1998): The avian heterophile leukocyte: a review. World's Poultry Science Journal 54: 155-178. https://doi.org/10.1079/WPS19980012

Markó, G., Jablonszky, M., Krenhardt, K., SzÁsz, E., TÖröK, J., ZsebÖK, S. \& Garamszegi, L. Z. (2016): Helyzetfüggő plaszticitás: támadási taktikák szerepe az örvös légykapó kockázatvállaló 
viselkedésében. In: A Magyar Etológiai Társaság XVIII. Konferenciája: Program és összefoglalók. Debrecen, Magyarország, p. 33

Mazerolle, D. F. \& Hobson, K. A. (2002): Physiological ramifications of habitat selection in territorial male Ovenbirds: Consequences of landscape fragmentation. Oecologia 130: 356-363. https://doi.org/10.1007/s00442-001-0818-z

Moreno, J., Merino, S., Martínez, J., Sanz, J. J. \& Arriero, E. (2002): Hererophil/lymphocyte ratios and heat-shock protein levels are related to growth in nestling birds. Écoscience 9(4), 434 439. https://doi.org/10.1080/11956860.2002.11682731

NAdOlSki, J., Skwarska, J., Kaliński, A., BAŃBura, M., ŚNiegula, R. \& BaŃBURA, J. (2006): Blood parameters as consistent predictors of nestling performance in great tits (Parus major) in the wild. Comparative Biochemistry and Physiology - A Molecular and Integrative Physiology 143: 50-54. https://doi.org/10.1016/j.cbpa.2005.10.021

Ochs, C. L. \& Dawson, R. D. (2008): Patterns of variation in leucocyte counts of female tree swallows, Tachycineta bicolor: Repeatability over time and relationships with condition and costs of reproduction. Comparative Biochemistry and Physiology - A Molecular and Integrative Physiology 150: 326-331. https://doi.org/10.1016/j.cbpa.2008.04.003

OTS, I., MuRUMÄGI, A. \& HõRAK, P. (1998): Haematological health state indices of reproducing Great Tits: Methodology and sources of natural variation. Functional Ecology 12: 700-707. https://doi.org/10.1046/j.1365-2435.1998.00219.x

Owen, J. C. \& Moore, F. R. (2006): Seasonal Differences in Immunological Condition of Three Species of Thrushes. The Condor 108: 389. https://doi.org/10.1093/condor/108.2.389

SILD, E., SEPP, T. \& HõRAK, P. (2011): Behavioural trait covaries with immune responsiveness in a wild passerine. Brain, Behavior, and Immunity 25: 1349-1354. https://doi.org/10.1016/j.bbi.2011.03.020

Speakman, J. R., Blount, J. D., Bronikowski, A. M., Buffenstein, R., Isaksson, C., Kirkwood, T. B. L., Monaghan, P., Ozanne, S. E., Beaulieu, M., Briga, M., Carr, S. K., Christensen, L. L., Cochemé, H. M., Cram, D. L., Dantzer, B., Harper, J. M., Jurk, D., King, A., Noguera, J. C., Salin, K., Sild, E., Simons, M.J., Smith, S., Stiuer, A., Tobler, M., Vitikainen, E., Peaker, M. \& Selman, C. (2015): Oxidative stress and life histories: Unresolved issues and current needs. Ecology and Evolution 5: 5745-5757. https://doi.org/10.1002/ece3.1790

SzÁsz, E., Jablonszky, M., Krenhardt, K., Markó, G., Hegyi, G., Herényi, M., Laczi, M., NAGy, G., Rosivall, B., SzÖLlÖSI, E., TÖRÖK, J. \& GARAMsZEGI, L. Z. (2019): Male territorial aggresion and fitness in collared flycatchers: a long-term study. The Science of Nature 106: 11. https://doi.org/10.1007/s00114-019-1606-0

Szöllösi, E., Garamszegi, L. Z., Hegyi, G., Laczi, M., Rosivall, B. \& TöröK, J. (2016): Haemoproteus infection status of collared flycatcher males changes within a breeding season. Parasitology Research 115: 4663-4672. https://doi.org/10.1007/s00436-016-5258-0 


\title{
Correlation between physiology and behavioural traits in a wild passerine
}

\section{GYULA SZABÓ $^{1 *}$, NÓRA BOROSS ${ }^{1,2}$, LÁSZLÓ ZSOLT GARAMSZEGI $^{1,3,4,5}$, GERGELY HEGYI ${ }^{1}$, MÓNIKA JABLONSZKY ${ }^{1}$, KATALIN KRENHARDT ${ }^{1}$, MIKLÓS LACZI ${ }^{1,6}$, GÁBOR MARKÓ $^{1,7}$, ESZTER SZÁSZ $^{1} \&$ JÁNOS TÖRÖK ${ }^{1,8}$}

\author{
${ }^{1}$ Behavioural Ecology Group, Department of Systematic Zoology and Ecology, \\ Eötvös Loránd University, Pázmány Péter sétány 1/C, H-1117 Budapest, Hungary \\ ${ }^{2}$ Balaton Limnological Institute, Centre for Ecological Research, Hungarian Academy of Sciences, \\ Klebersberg Kuno utca 3, H-8237 Tihany, Hungary \\ ${ }^{3}$ Institue of Ecology and Botany, Centre for Ecological Research, Hungarian Academy of Sciences, \\ Alkotmány utca 2-4, H-2163Vácrátót, Hungary \\ ${ }^{4}$ Departamento de Ecología Evolutiva, Estación Biológica de Donaña-CSIC, \\ C/Americo Vespucio, 26, 41092 Seville, Spain \\ ${ }^{5}$ MTA-ELTE Theoretical Biology and Evolutionary Ecology Research Group, \\ Department of Plant Systematics, Ecology and Theoretical Biology, \\ Eötvös Loránd University, Pázmány Péter sétány 1/C, H-1117 Budapest, Hungary \\ ${ }^{6}$ The Barn Owl Foundation, Temesvári út 8, H-8744 Orosztony, Hungary \\ ${ }^{7}$ Department of Plant Pathology, Szent István University, Villányi út 29-43, H-1118 Budapest, Hungary \\ ${ }^{8}$ Ecology Research Group of the Hungarian Academy of Sciences, \\ Pázmány Péter sétány 1/C, H-1117 Budapest, Hungary \\ *E-mail:szabogyula11@caesar.elte.hu
}

ÁLLATTANI KÖZLEMÉNYEK (2020) 105(1-2): 71-84.

\begin{abstract}
Despite the increasing number of studies describing behaviours, there are less knowledge of these behaviour's physiological background in wild populations. In this paper we investigated the relationship between health state, oxidative damage and behaviour in a wild collared flycatcher (Ficedula albicollis) population. We defined health state as the ratio of heterophil granulocytes and limphocytes (H/L ratio). The number and ratio of leukocytes were counted in bloodsmears. Lower leukocyte ratio reflects better health state and lower stress level. We used plasma levels of reactive oxygen metabolites (ROMs) to measure oxidative damage. We collected blood samples from males during the courtship period and the chick-rearing period, while females were sampled only in the chick-rearing period. With regards to behaviour, we quantified novelty avoidance, aggression and risk-taking of males during courtship. There were no differences between sexes in $\mathrm{H} / \mathrm{L}$ ratio and ROM levels. In one-year old males, ROM levels tended to be higher in the chick-rearing period. The correlation between H/L ratio and ROMs were significant only in females, namely lower oxidative damage associated with better health state. We found a correlation between novelty avoidance and ROM levels measured in the courtship period. The increase in ROMs might be caused by the demanding work of chick-rearing in one-year old males, while older males might have more experience in chick-rearing. Higher heterophil counts result in higher H/L ratio. Heterophils release radicals, which results in higher oxidative damage. Less novelty avoiding males might fly from a bigger distance to investigate novel objects getting close to its nest, resulting in a higher metabolism level, and higher plasma level of ROMs. More studies are needed for a deeper understanding of these patterns.
\end{abstract}

Keywords: oxidative damage, leukocyte ratio, aggression, risk-taking, novelty avoidance. 